\title{
PENGARUH STRES KERJA TERHADAP KINERJA PEGAWAI PADA DINAS PENDAPATAN, KEUANGAN DAN ASET DAERAH KABUPATEN MUSI MANYUASIN
}

\author{
Oleh : \\ Usailan Oemar \\ Fakultas Ekonomi STIE Rahmaniyah, Sekayu \\ Email : elanoemar11@yahoo.com \\ Leo Gangga \\ Fakultas Ekonomi STIE Rahmaniyah, Sekayu
}

\begin{abstract}
ABSTRAK
Stres kerja mengakibatkan kelelahan kerja, seringkali tanda awal dari stres kerja adalah suatu perasaan bahwa dirinya mengalami kelelahan emosional terhadap pekerjaan-pekerjaan. Bila diminta menjelaskan yang dirasakan, seorang karyawan yang lelah secara emosional akan merasa kehabisan tenaga dan lelah secara fisik.

Dinas Pendapatan, Pengelolaan Keuangan dan Aset Daerah Kabupaten Musi Banyuasin merupakan salah satu Satuan Kerja Perangkat Daerah (SKPD) di Kabupaten Musi Banyuasin yang bertugas melaksanakan urusan pemerintahan daerah bidang pendapatan, pengelolaan keuangan dan aset berdasarkan asas otonomi dan tugas pembantuan diseluruh Kabupaten Musi Banyuasin. Beratnya tugas Dinas Pendapatan, Pengelolaan Keuangan dan Aset Daerah Kabupaten Musi Banyuasin menyebabkan para pegawai pada dinas tersebut harus memiliki profesionalitas dan kinerja yang optimal.

Besarnya korelasi $(\mathrm{R})$ variabel stres kerja $(\mathrm{X})$ terhadap kinerja pegawai $(\mathrm{Y})$ adalah 0,791 artinya hubungan/ korelasi antara stres kerja terhadap kinerja pegawai Dinas Pendapatan, Pengelolaan Keuangan dan Aset Daerah Kabupaten Musi Banyuasin menunjukkan adanya hubungan/korelasi yang bersifat kuat dan positif. Besarnya pengaruh stres kerja terhadap kinerja pegawai Dinas Pendapatan, Pengelolaan Keuangan dan Aset Daerah Kabupaten Musi Banyuasindilihat dari nilai $R$ Square yaitu 0,624 yang memberikan pengertian bahwa $62,4 \%$ variabel kinerja pegawai $(\mathrm{Y})$ dapat dipengaruhi oleh variabel stres kerja (X), sedangkan sisanya 37,6\% dijelaskan oleh faktor lainnya.
\end{abstract}

Kata kunci : Stres Kerja, Kinerja Pegawai.

\section{Latar Belakang Masalah}

Pegawai merupakan salah satu aset yang sangat penting. Pegawai yang merupakan tenaga kerja bagi suatu organisasi dimana kadang kala sering diabaikan sebagai aset yang berharga. Tak jarang, suatu organisasi hanya mengganggap bahwa pegawai hanya sebagai beban yang harus selalu ditekan untuk mengurangi biaya. Namun, itu merupakan pandangan yang kurang tepat. Karena pegawai merupakan satu-satunya aset yang tidak dapat digandakan dan dicontoh oleh manusia lain karena pada hakekatnya tiap-tiap orang adalah makhluk unik yang diciptakan oleh Maha Pencipta dengan karakteristik yang berbeda-beda. Oleh karena itu diperlukan suatu manajemen sumber daya manusia yang bagi suatu organisasi.

Tujuan utama manajemen sumber daya manusia di setiap organisasi adalah untuk memfasilitasi kinerja organisasi. Kinerja organisasi ditentukan oleh kinerja pegawai sebagai seorang manusia individu di mana perilaku kerja menjadi sumber daya utama dalam mencapai tujuan organisasi yang diinginkan. Kinerja pegawai merupakan perilaku nyata yang dihasilkan setiap orang sebagai prestasi kerja yang dihasilkan oleh 
karyawan sesuai dengan perannya dalam perusahaan.

Salah satu faktor yang perlu diperhatikan oleh setiap organisasi agar kinerja sumber daya manusianya baik adalah adanya stres kerja pada pegawai. Menurut Robbins (2008:368). Stres kerja merupakan suatu kondisi keadaan seseorang mengalami ketegangan karena adanya kondisi yang mempengaruhi dirinya. Stres di tempat kerja merupakan hal yang hampir setiap hari dialami oleh para pegawai.

Persaingan dan tuntutan profesionalitas yang semakin tinggi menimbulkan banyaknya tekanan-tekanan yang harus dihadapi individu dalam lingkungan kerja. Para pegawai yang selalu disibukkan dengan deadline penyelesaian tugas, tuntutan peran di tempat kerja yang semakin beragam dan kadang bertentangan satu dengan yang lain, masalah keluarga, beban kerja yang berlebihan, dan masih banyak tantangan lainnya yang membuat stres menjadi suatu faktor yang hampir tidak mungkin untuk dihindari.

Dinas Pendapatan, Pengelolaan Keuangan dan Aset Daerah Kabupaten Musi Banyuasin merupakan salah satu Satuan Kerja Perangkat Daerah (SKPD) di Kabupaten Musi Banyuasin yang bertugas melaksanakan urusan pemerintahan daerah bidang pendapatan, pengelolaan keuangan dan aset berdasarkan asas otonomi dan tugas pembantuan diseluruh Kabupaten Musi Banyuasin. Beratnya tugas Dinas Pendapatan, Pengelolaan Keuangan dan Aset Daerah Kabupaten Musi Banyuasin menyebabkan para pegawai pada dinas tersebut harus memiliki profesionalitas dan kinerja yang optimal.

Berdasarkan hasil wawancara yang penulis lakukan dengan Kepala Bidang Keuangan diketahui bahwa terjadi stres kerja pada pegawai hal ini terlihat dari banyaknya beban kerja, adanya target kerja seperti target penerimaan pajak maupun retribusi daerah dan pada setiap akhir tahun pegawai harus melakukan lembur sampai jam 24.00 wib untuk melakukan proses pencairan SP2D seluruh SKPD yang ada di Kabupaten Musi Banyuasin.

Dilihat dari kinerja pegawainya diketahui bahwa pegawai pada Dinas Pendapatan, Pengelolaan Keuangan dan Aset Daerah Kabupaten Musi Banyuasin selalu disiplin saat masuk dan pulang bekerja. Selain itu berdasarkan laporan realisasi fisik dan keuangan tahun 2015 diketahui tingkat penggunaan dan penyerapan anggaran keuangan pada dinas tersebut sebesar 95\% yang pada Dinas Pendapatan, Pengelolaan Keuangan dan Aset Daerah Kabupaten Musi Banyuasin.

Melihat fenomena tersebut menjadi menarik untuk melakukan kajian tentang analisis "Pengaruh Stres Kerja Terhadap Kinerja Pegawai Pada Dinas Pendapatan, Pengelolaan Keuangan dan Aset Daerah Kabupaten Musi Banyuasin".

\section{Rumusan Masalah}

Berdasarkan latar belakang tersebut maka permasalahan yang ingin diteliti yaitu bagaimana pengaruh stres kerja terhadap kinerja pegawai pada Dinas Pendapatan, Pengelolaan Keuangan dan Aset Daerah Kabupaten Musi Banyuasin?

\section{Tujuan Penelitian}

Adapun tujuan dari penelitian ini adalah mengetahui pengaruh stres kerja terhadap kinerja pegawai pada Dinas Pendapatan,Pengelolaan Keuangan dan Aset Daerah Kabupaten Musi Banyuasin.

\section{Manfaat Penelitian}

Adapun manfaat yang diharapkan dari penelitian ini adalah sebagai berikut :

\section{Manfaat Teoritis}

\begin{tabular}{lllr}
\multicolumn{1}{c}{ Penelitian } & ini diharapkan & dapat \\
memperluas & wawasan & terhadap & ilmu \\
pengetahuan & terutama & dalam & bidang
\end{tabular}


manajemen Sumber Daya Manusia, khususnya dalam kajian yang berhubungan dengan stres kerja dan kinerja pegawai. Selain itu, itu penelitian ini diharapkan dapat bermanfaat bagi penelitian lain.

\section{Manfaat Praktis}

Dari aspek praktis kegunaan penelitian ini untuk mengetahui stres kerja pengaruhnya terhadap kinerja pegawai sebagai masukan kepada Dinas Pendapatan,Pengelolaan Keuangan dan Aset Daerah Kabupaten Musi Banyuasin

\section{Landasan Teori}

\section{Stres Kerja}

\section{a. Pengertian Stres Kerja}

Menurut Robbins (2008:368). stress merupakan kondisi dinamis seorang individu dihadapkan dalam kesempatan, keterbatasan, atau tuntutan sesuai dengan harapan dan hasil yang ingin dicapai dalam kondisi penting dan tidak menentu.

Pada dasarnya stress tidak selalu berdampak buruk bagi individu, hal tersebut berarti bahwa pada situasi atau kondisi tertentu stress yang dialami seorang individu akan memberikan akibat positif yang mengharuskan individu tersebut melakukan tugas lebih baik. Akan tetapi pada tingkat stress yang lebih tinggi atau stress ringan yang berkepanjangan akan menyebabkan menurunnya kinerja karyawan.

Dewasa ini para peneliti berpendapat bahwa stres tantangan, atau stres yang menyertai tantangan di lingkugan kerja (seperti memiliki banyak proyek, tugas dan tanggung), beroperasi sangat berbeda dari stres hambatan, atau stres yang menghalangi mencapai tujuan (birokrasi, politik kantor, kebingungan terkait tanggung jawab kerja). Sebagai definisi dapat dikatakan bahwa stres kerja merupakan kondisi ketegangan yang berpengaruh terhadap emosi, jalan pikiran dan kondisi fisik seseorang.
Stres kerja mengakibatkan kelelahan kerja, seringkali tanda awal dari stres kerja adalah suatu perasaan bahwa dirinya mengalami kelelahan emosional terhadap pekerjaan-pekerjaan. Bila diminta menjelaskan yang dirasakan, seorang karyawan yang lelah secara emosional akan merasa kehabisan tenaga dan lelah secara fisik.

\section{b. Faktor-faktor Penyebab Stress Kerja}

Menurut Robbins (2008:373), ada beberapa faktor penyebab stress kerja, antara lain: konflik antar pribadi dengan pimpinan, beban kerja yang sulit dan berlebihan, terbatasnya waktu untuk menyelesaikan pekerjaan, tekanan dan sikap kepemimpinan yang kurang adil dan tidak wajar

1. Konflik Kerja

Konflik kerja adalah ketidaksetujuan antara dua atau lebih anggota atau kelompok dalam organisasi yang timbul karena harus menggunakan sumber daya secara bersama-sama atau menjalankan kegiatan bersamasama, atau karena mempunyai status, tujuan, nilai-nilai dan persepsi yang berbeda. Konflik kerja juga merupakan kondisi yang dipersepsikan ada antara pihak-pihak yang merasakan adanya ketidaksesuaian tujuan dan peluang untuk mencampuri usaha pencapaian tujuan pihak lain.

2. Beban Kerja

Beban kerja adalah keadaan dimana karyawan dihadapkan pada sejumlah pekerjaan dan tidak mempunyai cukup waktu untuk menyelesaikan pekerjaannya. Karyawan juga merasa tidak memiliki kemampuan untuk menyelesaikan pekerjaan tersebut karena standar pekerjaan terlalu tinggi.

3. Waktu Kerja

Karyawan selalu dituntut untuk segera menyelesaikan tugas pekerja sesuai dengan yang telah ditentukan. Dalam melakukan pekerjaannya karyawan merasa dikejar oleh waktu untuk mencapai target kerja. 
4. Sikap Pimpinan

Dalam setiap organisasi kedudukan pemimpin sangat penting, seorang pemimpin melalui pengaruhnya dapat memberikan dampak yang sangat berarti terhadap aktifitas kerja karyawan. Dalam pekerjaan yang bersifat stessfull, para karyawan bekerja lebih baik jika pimpinannya mengambil tanggung jawab lebih besar dalam memberikan pengarahan.

\section{c. Sumber-Sumber Potensi Stres Kerja}

Ada tiga kategori penderita stres kerja potensial yakni lingkungan, organisasional, dan individual (Robbins, 2008:370):

1. Faktor Lingkungan

Ketidakpastian lingkungan mempengaruhi desain dari struktur organisasi, ketidakpastian itu juga mempengaruhi tingkat stres kerja di kalangan para karyawan dalam organisasi. Perubahan dalam siklus bisnis menciptakan ketidakpastian ekonomi. Bila ekonomi mengerut, orang menjadi mekin mencemaskan keamanan. Hal-hal tersebut dapat menjadi sumber- sumber stres kerja di kalangan karyawan.

2. Faktor Organisasi

Banyak sekali faktor di dalam organisasi yang dapat menimbulkan stres kerja. Tekanan untuk menghindari kekeliruan atau menyelesaikan tugas dalam suatu kurun waktu yang terbatas, beban kerja yang berlebihan, serta rekan kerja yang tidak menyenangkan. Faktor-faktor ini dapat dikategorikan pada tuntutan tugas, tuntutan peran, dan tuntutan hubungan antar pribadi, struktur organisasi, kepemimpinan organisasi, dan tingkat hidup organisasi. Menurut Monday (2008: 96) faktor-faktor keorganisasian meliputi budaya perusahaan, pekerjaan seseorang, dan kondisi kerja. Budaya perusahaan banyak berhubungan dengan stres. Gaya kepemimpinan sering mempengaruhi suasana. Di samping itu, persaingan yang didorong oleh sistem balas jasa organisasi untuk promosi, kenaikan bayaran, dan status juga bisa menambah masalahSejumlah faktor yang berhubungan dengan pekerjaan yang dijalankan seseorang bisa menyebabkan stres berlebihan. Beberapa pekerjaan dipersepsikan lebih penuh stres dibandingkan yang lain karena karakteristik tugas yang harus dikerjakan serta tingkat tanggung jawab dan kontrol yang dimungkinkan oleh pekerjaan. Kondisi kerja termasuk karakteristik fisik tempat kerja serta mesin dan perkakas yang digunakan juga bisa menciptakan stres. Kelebihan beban kebisingan yang berlebihan, pencahayaan yang kurang, pemeliharaan tempat kerja yang buruk, dan peralatan yang rusak secara umum bisa berpengaruh buruk pada semangat kerja karyawan dan meningkatkan stres.

3. Faktor Individual Lazimnya individu hanya bekerja 40 sampai 50 jam sepekan. Namun pengalaman dan masalah yang dijumpai orang di luar jam kerja yang lebih dari 120 jam tiap pekan dapat melebihi dari pekerjaan. Maka kategori ini mencakup faktor-faktor dalam kehidupan pribadi karyawan. Terutama sekali faktor-faktor ini adalah persoalan keluarga, masalah ekonomi pribadi, dan kateristik kepribadian bawaan.

Menurut Efendi (2007: 115) penyebab stres yaitu:

1. Kondisi Pekerjaan. Kondisi pekerjaan dan lingkungan kerja yang terlalu menekan (kebisingan, temperatur, udara yang lembab, penerangan dikantor yang kurang terang serta beban kerja yang tidak seimbang

2. Masalah Peran. Adanya pemisahan tugas dan fungsi dari masing-masing pegawai

3. Hubungan Interpersonal. Hubungan interpersonal pegawai dengan atasan ataupun rekan kerja

4. Kesempatan pengembangan karir yaitu tersedia atau tidaknya kesempatan bagi pegawai untuk mengembangkan karir dalam suato organisasi atau perusahaan 
5. Struktur dan Iklim Organisasi. Adanya kejelasan dalam pembagian tugas dan wewenang dari masing-masing pegawai.

\section{Kinerja Pegawai}

\section{a. Pengertian Kinerja Pegawai}

Definisi Kinerja Suatu organisasi, baik itu pemerintah maupun swasta, selalu digerakan oleh sekelompok orang yang berperan aktif untuk mencapai tujuan yang ingin dicapai dari organisasi tersebut. Tujuan organisasi tentunya tidak akan tercapai jika kinerja anggota atau pegawainya tidak maksimal. Menurut Siagian (2007:227), mendefinisikan kinerja sebagai suatu keseluruhan kemampuan seseorang untuk bekerja sedemikian rupa sehingga mencapai tujuan kerja secara optimal dan berbagai sasaran yang telah diciptakan dengan pengorbanan yang secara rasio lebih kecil dibandingkan dengan hasil yang dicapai.

Berbagai pendapat diatas dapat menggambarkan bahwa kinerja pegawai dan kinerja organisasi memiliki keterkaitan yang sangat erat, tercapainya tujuan organisasi tidak bisa dilepaskan dari sumber daya yang dimiliki oleh organisasi yang digerakan atau dijalankan pegawai yang berperan aktif sebagai pelaku dalam upaya mencapai tujuan organisasi.Jadi dapat disimpulkan bahwa kinerja pegawai adalah penilaian hasil kerja seseorang dalam suatu organisasi sesuai dengan tugas dan tanggungjawabnya dalam rangka mencapai tujuan organisasi.

\section{b. Faktor Faktor yang Mempengaruhi Kinerja Pegawai}

Menurut Moorhead dan Chung/ dalam Sugiono (2009:12) kinerja pegawai dipengaruhi oleh beberapa faktor, yaitu:

1. Kualitas Pekerjaan (Quality of Work), merupakan tingkat baik atau buruknya sesuatu pekerjaan yang diterima bagi seorang pegawai yang dapat dilihat dari segi ketelitian dan kerapihan kerja, keterampilan dan kecakapan.

2. Kuantitas Pekerjaan (Quantity of Work), merupakan seberapa besarnya beban kerja atau sejumlah pekerjaan yang harus diselesaikan oleh seorang pegawai. Diukur dari kemampuan secara kuantitatif didalam mencapai target atau hasil kerja atas pekerjaan-pekerjaan baru.

3. Pengetahuan Pekerjaan (Job Knowledge), merupakan proses penempatan seorang pegawai yang sesuai dengan background pendidikan atau keahlian dalam suatu pekerjaan. Hal ini ditinjau dari kemampuan pegawai dalam memahami hal-hal yang berkaitan dengan tugas yang mereka lakukan.

4. Kerjasama Tim (Teamwork). Melihat bagaimana seorang pegawai bekerja dengan orang lain dalam menyelesaikan suatu pekerjaan. Kerjasama tidak hanya sebatas secara vertikal ataupun kerjasama antar pegawai, tetapi kerjasama secara horizontal merupakan faktor penting dalam suatu kehidupan organisasi yaitu dimana antar pimpinan organisasi dengan para pegawainya terjalin suatu hubungan yang kondusif dan timbal balik yang saling menguntungkan.

5. Kreatifitas (Creativity). Merupakan kemampuan seorang pegawai dalam menyelesaikan pekerjaannya dengan cara atau inisiatif sendiri yang dianggap mampu secara efektif dan efisien serta mampu menciptakan perubahanperubahan baru guna perbaikan dan kemajuan organisasi.

6. Inovasi (Inovation). Kemampuan menciptakan perubahan-perubahan baru guna perbaikan dan kemajuan organisasi. Hal ini ditinjau dari ide-ide cemerlang dalam mengatasi permasalahan organisasi.

7. Inisiatif (initiative). Melingkupi beberapa aspek seperti kemampuan untuk mengambil langkah yang tepat dalam menghadapi kesulitan, kemampuan untuk melakukan sesuatu pekerjaan tanpa bantuan, kemampuan untuk mengambil tahapan pertama dalam kegiatan.

\section{c. Indikator Kinerja Pegawai}

Menurut Keban dalam Pasolong (2010:184) pengukuran kinerja pegawai 
penting dilakukan oleh instansi pelayanan publik.Dengan mengetahui kelemahan dan kelebihan, hambatan dan dorongan, atau berbagai faktor sukses bagi kinerja pegawai serta institusi maka terbukalah jalan menuju profesionalisasi, yaitu memperbaiki kesalahan-kesalahan yang dilakukan selama ini. Terdapat berbagai teori mengenai indikator kinerja pegawai. Salah satunya indikator kinerja pegawai Fadel (2009:195) mengemukakan beberapa indikator yang digunakan untuk mengukur kinerja pegawai yaitu :

1. Pemahaman atas tupoksi.Dalam menjalankan tupoksi, bawahan harus terlebih dahulu paham tentang tugas pokok dan fungsi masing-masing serta mengerjakan tugas sesuai dengan apa yang menjadi tanggung jawabnya.

2. Inovasi. Memiliki inovasi yang positif dan menyampaikan pada atasan serta mendiskusikanya pada rekan kerja tentang pekerjaan.

3. Kecepatan kerja Dalam menjalankan tugas kecepatan kerja harus diperhatikan dengan menggunakan mengikuti metode kerja yang ada.

4. Keakuratan kerja Tidak hanya cepat, namun dalam menyelesaikan tugas karyawan juga harus disiplin dalam mengerjakan tugas dengan teliti dalam bekerja dan melakukan pengecekan ulang.

5. Kerjasama Kemampuan dalam bekerja sama dengan rekan kerja lainya seperti bisa menerima dan menghargai pendapat orang lain.

Selain pendapat para ahli, pemerintah memiliki indikator kinerja pegawai yaitu dalam Undang-Undang Nomor 43 Tahun 1999 tentang penilaian pelaksanaan pekerjaan PNS. Indikator tersebut adalah:

1. Kesetiaan, yaitu tekat dan kesanggupan untuk menaati, melaksanakan, dan mengamalkan sesuatu yang ditaati dengan penuh kesabaran dan tanggungjawab.

2. Prestasi kerja, yaitu hasil kerja yang dicapai pegawai dalam melaksanakan tugas yang diberikan kepadanya.

3. Tanggungjawab, yaitu kesanggupan pegawai dalam melakukan pekerjaan yang diserahkan kepadanya dengan sebaikbaiknya dan tepat waktu, serta berani menanggung resiko atas keputusan yang telah diambil. d) Ketaatan, yaitu kesanggupan pegawai untuk menaati segala peraturan perundang-undangan dan peraturan kedinasan yang berlaku.

4. Kejujuran, yaitu ketulusan hati pegawai dalam melaksanakan dan kemampuan untuk tidak menyalahgunakan wewenang yang diembannya.

5. Kerjasama, yaitu kemampuan pegawai untuk bekerjasama dengan orang lain dalam melakukan tugasnya.

6. Prakarsa, yaitu kemampuan pegawai untuk mengambil keputusan langkahlangkah atau melaksanakan semua tindakan yang diperlukan dalam melaksanakan tugas pokok tanpa menunggu perintah dari atasan.

7. Kepemimpinan, yaitu kemampuan untuk mempengaruhi orang lain sehingga dapat diarahkan secara maksimal untuk melaksanakan tugas.

Menurut Sulistiyani (2009: 85), ada 3 hal yang dapat dijadikan indikator kinerja pegawai antara lain:

1. Kualitas, menyangkut kesesuaian hasil dengan yang diinginkan.

2. Kuantitas, yaitu jumlah yang dihasilkan baik dalam nilai uang, jumlah unit atau jumlah lingkaran aktifitas.

3. Sikap Karyawan, yaitu perilaku-perilaku yang berkaitan dengan pekerjaan.

\section{d. Penelitian Terdahulu}

Penelitian Rita Swietenia, tahun 2009. "Analisis Pengaruh Kepemimpinan, Kompensasi dan Karakteristik Pekerjaan Terhadap Disiplin Kerja Serta Implikasinya Terhadap Kinerja Pegawai (Studi Pada Kantor Pertanahan Kota Semarang)." hasilnya menyimpulkan Kepemimpinan, Kompensasi dan Karateristik Pekerjaan Terhadap Disiplin Kerja Serta Implikasinya Tehadap Kinerja Pegawai berkolasi kuat dan positif serta berpengaruh terhadap displin 
kerja maupun implikasinya terhadap kinerja pegawai.

\section{Kerangka Pemikiran}

Berdasarkan rumusan masalah dan tujuan penelitian, penulis membuat kerangka pemikiran secara teoritis dijelaskan hubungan variabel terikat dan variabel bebas sebagai berikut:

Variabel independen Variabel Dependen

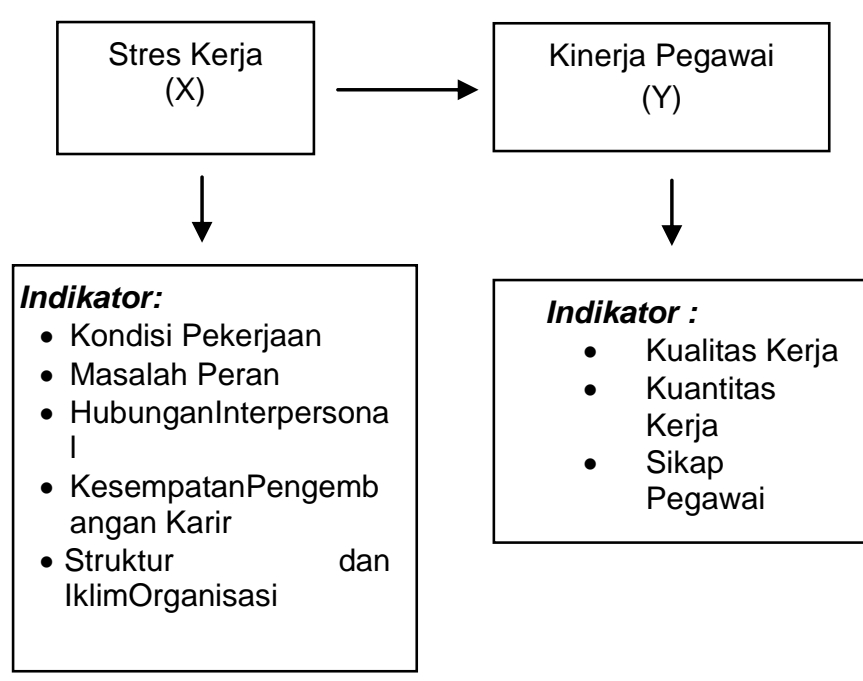

Gambar.1

Kerangka Pemikiran

\section{Hipotesis Penelitian}

Berdasarkan latar belakang dan rumusan masalah yang ada maka penulis menyusun hipotesis yaitu:

Ho: Stres kerja tidak berpengaruh signifikan terhadap kinerja pegawai pada Dinas Pendapatan, Pengelolaan Keuangan dan Aset Daerah Kabupaten Musi Banyuasin.

Ha: Stres kerja berpengaruh signifikan terhadap kinerja pegawai pada Dinas Pendapatan, Pengelolaan Keuangan dan Aset Daerah Kabupaten Musi Banyuasin.

\section{Metodologi Penelitian}

\section{Lokasi Penelitian}

Objek penelitian adalah Dinas Pendapatan, Pengelolaan Keuangan dan
Aset Daerah Kabupaten Musi Banyuasin yang beralamat di Jalan Kolonel Wahid Udin Kelurahan Serasan Jaya Kecamatan Sekayu Kabupaten Musi Banyuasin.

\section{Metode Penelitian}

Desain penelitian yang akan digunakan adalah model regresi linear sederhana, yaitu desain penelitian yang akan mengungkap pengaruh parsial variabel bebas terhadap variabel terikat. Penggunaan desain penelitian untuk membuktikan hipotesis yang telah disusun.

\section{Populasi dan Sampel Penelitian}

\section{a. Populasi}

Menurut Sugiyono (2009:81), populasi adalah wilayah generalisasi yang terdiri atas obyek/subyek yang mempunyai kualitas dan karakteristik tertentu yang ditetapkan oleh peneliti untuk dipelajari dan kemudian ditarik kesimpulannya. Populasi pada penelitian ini adalah pegawai Dinas Pendapatan, Pengelolaan Keuangan dan Aset Daerah Kabupaten Musi Banyuasin yang berjumlah 82 orang.

\section{b. Sampel}

Sedangkan sampel dalam penelitian adalah seluruh pegawai Dinas Pendapatan, Pengelolaan Keuangan dan Aset Daerah Kabupaten Musi Banyuasin yang berjumlah 82 orang. Untuk itu teknik pengambilan sampel yang digunakan adalah sampel jenuh. Menurut Sugiyono (2009: 54), sampel jenuh adalah teknik pengambilan sampel bila semua anggota populasi digunakan sebagai sampel.

\section{Sumber Data}

Menurut sumbernya, data yang digunakan adalah data primer Sugiyono (2009: 86), berupa data wawancara dan jawaban kuesioner para responden yang merupakan pegawai pada Dinas Pendapatan, Pengelolaan Keuangan dan Aset Daerah Kabupaten Musi Banyuasin. 


\section{Teknik Pengumpulan Data}

Pengumpulan data dengan menggunakan kuesioner yaitu dengan cara memberi seperangkat pertanyaan atau pertanyaan tertulis kepada Dinas Pendapatan, Pengelolaan Keuangan dan Aset Daerah Kabupaten Musi Banyuasin. Dari hasil kuesioner tersebut data yang didapat dianalisis secara kuantitatif, dimana skala yang digunakan dalam penelitian ini adalah skala Likert. Ghozali (2009:12).

\section{Teknik Analisis Data}

Analisis data yang akan digunakan dalam penelitian ini menggunakan SPSS versi 21. Adapun analisis data yang digunakan adalah anaisis regresi linear sederhana untuk mengetahui pengaruh stres kerja terhadap kinerja pegawai itu sendiri data juga dianalisis statistik dengan menggunakan SPSS. Adapun uji yang dilakukan berupa:

\section{a. Uji Validitas}

Uji validitas digunakan untuk mengukur sah atau valid tidaknya suatu kuesioner. Suatu kuesioner dikatakan valid jika pertanyaan pada kuesioner mampu untuk mengungkapkan sesuatu yang akan diukur oleh kuesioner tersebut . Untuk mengukur validitas dapat dilakukan dengan menggunakan Pearson Correlation antar skor butir pertanyaan dengan total skor konstruk atau variabel, tiap pertanyaan/pernyataan lebih besar atau $t_{\text {hitung }}>r_{\text {table }}$ barulah dikatakan valid.

2. Uji Reliabilitas

Uji reliabilitas adalah alat untuk mengukur suatu kuesioner yang mempunyai indikator dari variabel atau konstruk. Suatu konstruk atau variabel dikatakan reliabel jika memberikan nilai Cronbanch Alpha> 0,60.

3. Analisis Regresi Linear Sederhana

Analisis regresi linear sederhana adalah analisis yang hanya berkaitan dengan dua variabel saja, satu disebut variabel independen atau variabel bebas biasanya diberi notasi $X$, sedangkan variabel satunya disebut sebagai variabel dependen atau variabel terikat yang biasa diberi notasi Y. Regresi linear sederhana mengikuti persamaan dibawah ini

$\mathrm{Y}=\mathrm{a}+\mathrm{b} X$

Dimana:

$\mathrm{Y}=$ merupakan variabel terikat (kinerja pegawai)

$\mathrm{X}=$ Sebagai variabel bebas (stres kerja)

$\alpha=$ konstanta

$\mathrm{b}=$ koefisien regresi yang menunjukkan angka peningkatan atau

\section{Pengujian Hipotesis}

Hipotesis dalam penelitian menggunakan analisis regresi linear sederhana. Kriteria yang digunakan untuk hipotesis tersebut adalah:

- Ho diterima apabila nilai konstanta/probabilitasnya > taraf nyatanya $(\alpha=0,05)$

- Ha diterima apabila nilai konstanta/probabilitasnya $<$ taraf nyatanya $(\alpha=0,05)$

\section{PEMBAHASAN}

\section{Distribusi Karakteristik Responden dan Jawaban Kuesioner}

\section{a. Distribusi Karakteristik Responden}

Penelitian ini menggunakan pendapat 82 orang pegawai Dinas Pendapatan, Pengelolaan Keuangan dan Aset Daerah Kabupaten Musi Banyuasin yang merupakan responden dalam penelitian ini. Hasil pengisisan kuesioner oleh responden menunjukkan bahwa terdapat beberapa karakteristik mengenai responden antara lain 
berdasarkan: kelompok jenis kelamin, jenjang pendidikan, dan pengalaman kerja.

Uraian tentang karakteristik responden berdasarkan jenis kelamin, usia, dan masa kerja dapat dilihat pada Tabel 1. dibawah ini.

\section{Tabel.1}

\section{Distribusi Karakteristik Responden}

\begin{tabular}{|l|l|c|c|}
\hline \multicolumn{2}{|c|}{ Keterangan } & Jumlah & $\%$ \\
\hline Jenis \\
Kelamin & Laki-laki & 45 & 55 \\
\cline { 2 - 4 } & Perempuan & 37 & 45 \\
\cline { 2 - 4 } & Jumlah & $\mathbf{8 2}$ & $\mathbf{1 0 0}$ \\
\hline \multirow{2}{*}{$\begin{array}{l}\text { Jenjang } \\
\text { Pendidikan }\end{array}$} & SMA\& & 9 & 11 \\
& Diploma II & & \\
\cline { 2 - 4 } & Strata Satu & 45 & 55 \\
\cline { 2 - 4 } & Strata Dua & 28 & 34 \\
\cline { 2 - 4 } & Jumlah & $\mathbf{8 2}$ & $\mathbf{1 0 0}$ \\
\hline \multirow{4}{*}{$\begin{array}{l}\text { Pengalaman } \\
\text { Kerja }\end{array}$} & $<5$ Tahun & 32 & 39 \\
\cline { 2 - 4 } & $5-10$ tahun & 39 & 48 \\
\cline { 2 - 4 } & $>10$ tahun & 11 & 13 \\
\cline { 2 - 4 } & Jumlah & $\mathbf{8 2}$ & $\mathbf{1 0 0}$ \\
\hline
\end{tabular}

Sumber: DPPKAD Kab. Musi Banyuasin, 2015

Berdasarkan data dari tabel diatas diketahui bahwa dari jenis kelaminnya, 55\% atau sekitar 45 orang pegawai Dinas Pendapatan, Pengelolaan Keuangan dan Aset Daerah Kabupaten Musi Banyuasin berjenis kelamin laki-laki sedangkan sisanya $45 \%$ atau 37 orang berjenis kelamin perempuan. Dilihat dari jenjang pendidikannya $11 \%$ atau sekitar 9 orang merupakan lulusan SMA dan Diploma III, 55\% atau 45 orang merupakan lulusan Strata Satu dan 34\% atau 28 orang merupakan lulusan Strata Dua. Dilihat dari pengalaman pegawai Dinas Pendapatan, Pengelolaan Keuangan dan Aset Daerah Kabupaten Musi Banyuasin diketahui bahwa $39 \%$ atau 32 orangmemilikipengalaman kerja kurang dari 5 tahun $48 \%$ atau 39 orang memiliki pengalaman kerja selama 5 sampai 10 tahun sedangkan $13 \%$ atau 11 orang memiliki pengalaman kerja lebih dari 10 tahun.

\section{b. Distribusi Jawaban Responden}

Hasil jawaban 82 responden yang menjawab untuk pertanyaan yang berhubungan dengan stres kerja pegawai pada Dinas Pendapatan, Pengelolaan Keuangan dan Aset Daerah Kabupaten Musi Banyuasin sebagai berikut:

- Untuk pertanyaan lingkungan kerja anda memberikan kenyamanan bagi anda dalam bekerja, yang menjawab setuju $63 \%$, sedangkan sisanya $37 \%$ menjawab sangat setuju.

- Untuk pertanyaan pekerjaan yang anda lakukan melebihi kemampuan yang anda miliki, yang menjawab setuju 69\%, sedangkan sisanya $31 \%$ menjawab sangat setuju.

Untuk pertanyaan sering terjadi ketidakjelasan tugas dan taggung jawab dalam bekerja, yang menjawab setuju $76 \%$, sedangkan sisanya $24 \%$ mnejawab sangat setuju.

Untuk pertnyaan Anda selalu bekerja sama dengan rekan kerja anda dengan baik, yang menjawab setuju $70 \%$, sedangkan sisanya $30 \%$ menjawab sangat setuju.

- Untuk pertnyaan Anda memiliki hubungan yang baik dengan atasan anda, yang menjawab setuju $76 \%$, sedangkan sisanya $24 \%$ menjawab sangat setuju.

- Untuk pertanyaan tempat anda bekerja memberikan kesempatan bagi anda untuk pengembangan karir, yang menjawab cukup setuju 27\%( 22), sedangkan sisanya $73 \%$ menjawab setuju.

Untuk pertnyaan Anda mendapatkan kejelasan perintah dari atasan atas pekerjaan yang anda lakukan, yang menjawab setuju $73 \%$, sedangkan sisanya $27 \%$ menjawab sangat setuju

Untuk pertanyaan Anda mendapatkan kejelasan wewenang anda atas tugas yang anda lakukan, yang menjawab 
setuju 63\%, sedangkan sisanya $37 \%$ menjawab sangat setuju.

Berdasarkan hasil jawaban responden untuk pertanyaan yang berhubungan dengan kinerja pegawai diketahui bahwa, 83\% responden setuju jika mereka dalam bekerja akurat dan jarang melakukan kesalahan sedangkan sisanya $17 \%$ menjawab cukup setuju. Dilihat dari pertanyaan apakah responden mampu bekerja sesuai dengan standar pekerjaan, $71 \%$ menjawab cukup setuju sedangkan sisanya $16 \%$ menjawab tidak setuju dan $13 \%$ menjawab setuju.

Dilihat dari pertanyaan apakah responden dapat menyelesaikan beban kerja dengan baik tanpa harus dibantu, 54\% responden menjawab cukup setuju sedangkan sisanya $46 \%$ menjawab setuju. Untuk pertanyaan apakah responden tepat waktu dalam menyelesaikan pekerjaan, 52\% responden menjawab cukup setuju sedangkan sisanya $48 \%$ menjawab setuju. Untuk pertanyaan apakah responden selalu hadir dan pulang bekerja sesuai dengan waktu yang telah ditentukan, $84 \%$ responden menjawab setuju sedangkan sisanya $16 \%$ menjawab cukup setuju.

Untuk pertanyaan apakah responden selalu memotivasi pegawai lain untuk dapat bekerja sebaik mungkin, $72 \%$ responden menjawab cukup setuju sedangkan sisanya $17 \%$ menjawab tidak setuju dan $11 \%$ menjawab setuju.Untuk pertanyaan apakah responden mampu mengerjakan tugas tambahan yang diberikan atasan anda dengan tepat waktu tanpa mengganggu tugas sehari hari anda, $50 \%$ responden menjawab cukup setuju sedangkan sisanya $50 \%$ menjawab setuju.
Untuk pertanyaan apakah responden merasa terbantu untuk melaksanakan pekerjaan dengan cepat dan tepat waktu dengan adanya komunikasi dengan atasan, $55 \%$ responden menjawab cukup setuju sedangkan sisanya $45 \%$ menjawab setuju.Untuk pertanyaan apakah responden dapat bekerjasama dengan pegawai lain untuk mencapai tujuan organisasi, $84 \%$ responden menjawab setuju sedangkan sisanya $16 \%$ menjawab sangat setuju. Untuk pertanyaan apakah responden selalu bertanggung jawab atas pekerjaan yang anda dapatkan, $80 \%$ responden menjawab setuju sedangkan sisanya $20 \%$ menjawab sangat setuju.

Dari hasil jawaban 82 responden dapat disimpulkan bahwa masih ada responden yang belum mampu bekerja sesuai dengan standar perusahaan dan mengerjakan tugas tambahan yang diberikan atasan anda dengan tepat waktu tanpa mengganggu tugas sehari hari.

\section{Hasil Pengujian}

\section{a. Regresi Linear Sederhana}

Seperti yang telah dikemukakan sebelumnya, regresi linear sederhana digunakan untuk melihat pengaruh variabel $X$ (stres kerja ) terhadap variabel Y (kinerja pegawai) dalam penelitian ini, maka dilakukan regresi linear sederhana. Adapun hasil dari regresi linear sederhana yang telah penulis lakukan didapat hasil sebagai berikut:

Tabel 2

Hasil Koefisien Regresi

Pengaruh stres kerja terhadap kinerja pegawai

\begin{tabular}{|l|l|r|r|r|r|r|}
\hline Model & & $\begin{array}{c}\text { Unstandardized } \\
\text { Coefficients }\end{array}$ & $\begin{array}{c}\text { Standardized } \\
\text { Coeffici }\end{array}$ & & $\mathrm{t}$ & \multicolumn{1}{c|}{ Sig. } \\
\hline & & B & Std. Error & Beta & & \\
\hline 1 & (Constant) & 22,374 & 4,512 & & & \\
\hline & $\mathrm{X}$ &, 106 &, 158 &, 079 &, 670 &, 001 \\
\hline
\end{tabular}

Sumber: Data diolah Penulis dengan program SPSS versi 21, 2016 
Berdasarkan hasil analisis koefisien regresi sederhana pada tabel 2. tersebut diketahui bahwa persamaan regresi linear sederhana pengaruh stres kerja (X) terhadap kinerja pegawai (Y) adalah:

$$
Y=22,374+0,106 X
$$

Dari persamaan di atas dapat dijelaskan bahwa konstanta regresi adalah 22,374 dan koefisien regresi stres kerja adalah 0,106 artinya, jika variabel stres kerja dinaikkan sebesar 1 poin maka kinerja pegawai juga akan naik sebesar 0,106

Sedangkan untuk melihat besarnya hubungan antara variabel tersebut perlu dilakukan analisis koefisien korelasi, hasil analisis korelasi dapat dilihat pada tabel. 3 berikut ini :

\section{Tabel. 3}

\section{Koefisien Korelasi dan Determinasi Pengaruh stres kerja terhadapkinerja pegawai}

Model Summary

\begin{tabular}{|c|c|r|r|r|}
\hline Model & $\mathrm{R}$ & $\begin{array}{c}\mathrm{R} \\
\text { Square }\end{array}$ & $\begin{array}{c}\text { Adjusted R } \\
\text { Square }\end{array}$ & $\begin{array}{r}\text { Std. Error } \\
\text { e Estimate }\end{array}$ \\
\hline 1 &, $791^{\mathrm{a}}$ &, 624 &, 850 & 2,42383 \\
\hline
\end{tabular}
program SPSS versi 21, 2016

Berdasarkan Tabel. 3 di atas menunjukan hubungan/korelasi $(\mathrm{R})$ variabel stres kerja (X) terhadap terhadap kinerja pegawai (Y) adalah 0,791, artinya hubungan stres kerja terhadap kinerja pegawai Dinas Pendapatan, Pengelolaan Keuangan dan Aset Daerah Kabupaten Musi Banyuasin menunjukkan adanya korelasi yang bersifat kuat dan positif. Untuk mengetahui berapa besar hubungan tersebut dapat dilihat dari nilai Adjusted $R$ Square yaitu 0,850 yang memberikan pengertian bahwa $85 \%$ variabel kinerja pegawai(Y) dipengaruhi oleh variabel stres kerja (X), sedangkan sisanya $15 \%$ dijelaskan oleh faktor lainnya.

\section{b. Pengujian Hipotesis}

Pengujian hipotesis dilakukan untuk mengetahui apakah variabel $\mathrm{X}$ berpengaruh signifikan terhadap variabel Y. Berikut data hasil output SPSS untuk uji signifikasi.

Tabel. 4

Hasil Uji Signifikansi

Pengaruh stres kerja terhadap kinerja pegawai

Coefficients(a)

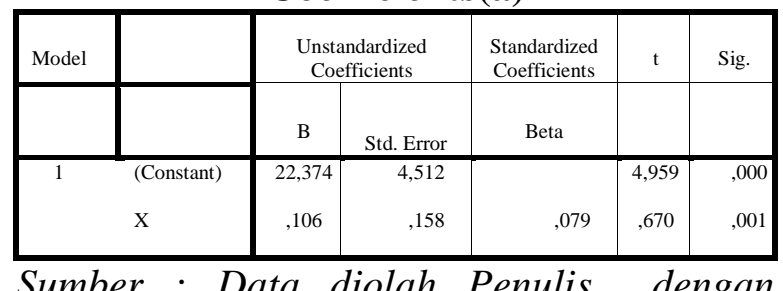

program SPSS versi 21, 2015

Berdasarkan hasil analisis koefisien regresi sederhana pada tabel 4. tersebut, dari kolom Unstandardized Coefficients dapat dilihat bahwa pada kolom Sig/Significance untuk baris konstanta $(22,374)$ nilainya dibawah 0,05 yaitu 0,000 artinya pada tingkat kepercayaan $95 \% \mathrm{H}_{0}$ ditolak dan $\mathrm{Ha}$ diterima dan itu berarti bahwa stres kerja berpengaruh signifikan terhadap kinerja pegawai pada Dinas Pendapatan, Pengelolaan Keuangan dan Aset Daerah Kabupaten Musi Banyuasin.

\section{Hasil Penelitian}

Berdasarkan hasil pembahasan di atas pengaruh stres kerja terhadap kinerja pegawai Dinas Pendapatan, Pengelolaan Keuangan dan Aset Daerah Kabupaten Musi Banyuasin menunjukkan adanya korelasi yang bersifat kuat $(79.1 \%)$ dan positif dan pengaruh yang signifikan terhadap kinerja pegawai Dinas Pendapatan, Pengelolaan Keuangan dan Aset Daerah Kabupaten Musi Banyuasin.

Hal tersebut juga dibuktikan dengan besar pengaruh tersebut dapat dilihat dari nilai $\quad R$ Square yaitu 0,624 yang memberikan pengertian bahwa $62,4 \%$ 
variabel kinerja pegawai(Y) dipengaruhi oleh variabel stres kerja (X), sedangkan sisanya $37,6 \%$ dijelaskan oleh faktor lainnya.

Hasil uji hipotesis (uji t) antara stres kerja dan kinerja pegawai juga menunjukkan bahwa Ho ditolak dan $\mathrm{Ha}$ diterima yang berarti bahwa stres kerja berpengaruh signifikan terhadap kinerja pegawai pada Dinas Pendapatan, Pengelolaan Keuangan dan Aset Daerah Kabupaten Musi Banyuasin karena nilai konstanta/probabilitasnya $<$ taraf nyatanya $(\alpha=0,05)$ yaitu 0,000 .

\section{SIMPULAN DAN SARAN}

\section{Simpulan}

Dari hasil pembahasan pada bab sebelumnya dapat disimpulkan:

1. Besarnya pengaruh stres kerja (X) terhadap kinerja pegawai (Y) adalah $Y=$ $22,374+0,106 X$ yang artinya konstanta regresi adalah 22,374 dan koefisien regresi stres kerja adalah 0,106 Artinya, jika variabel stres kerja dinaikkan sebesar 1 poin maka kinerja pegawai juga akan naik sebesar 0,106.

2. Besarnya korelasi (R) variabel stres kerja (X) terhadap kinerja pegawai $(\mathrm{Y})$ adalah 0,791 artinya hubungan/ korelasi antara stres kerja terhadap kinerja pegawai Dinas Pendapatan, Pengelolaan Keuangan dan Aset Daerah Kabupaten Musi Banyuasin menunjukkan adanya hubungan/korelasi yang bersifat kuat dan positif. Besarnya pengaruh stres kerja terhadap kinerja pegawai Dinas Pendapatan, Pengelolaan Keuangan dan Aset Daerah Kabupaten Musi Banyuasindilihat dari nilai $R$ Square yaitu 0,624 yang memberikan pengertian bahwa $62,4 \%$ variabel kinerja pegawai (Y) dapat dipengaruhi oleh variabel stres kerja $(\mathrm{X})$, sedangkan sisanya $37,6 \%$ dijelaskan oleh faktor lainnya.

3. Hasil uji hipotesis (uji t) antara stres kerja dan kinerja pegawai menunjukkan bahwa Ho ditolak dan Ha diterima yang berarti bahwa stres kerja berpengaruh signifikan terhadap kinerja pegawai pada Dinas Pendapatan, Pengelolaan Keuangan dan Aset Daerah Kabupaten Musi Banyuasin karena nilai konstanta/probabilitasnya $<$ taraf nyatanya $(\alpha=0,05)$ yaitu 0,000 .

\section{Saran}

Adapun saran yang dapat dikemukakan penulis dalam rangka membantu dalam meningkatkan pegawai Dinas Pendapatan, Pengelolaan Keuangan dan Aset Daerah Kabupaten Musi Banyuasin, adalah sebagai berikut:

1. Hendaknya pimpinan Dinas Pendapatan, Pengelolaan Keuangan dan Aset Daerah Kabupaten Musi Banyuasin dapat menjalin komunikasi yang baik dengan para pegawainya sehingga terjalin hubungan yang baik antara atasan dan bawahannya.

2. Hendaknya pegawai Dinas Pendapatan, Pengelolaan Keuangan dan Aset Daerah Kabupaten Musi Banyuasin dapat terus bekerja sesuai dengan standar yang telah ditetapkan dinas serta mampu mengerjakan tugas tambahan yang diberikan atasan anda dengan tepat waktu tanpa mengganggu tugas seharihari. 


\section{DAFTAR PUSTAKA}

Efendi, Hariandja Marihot Tua. 2007. Manajemen Sumber Daya Manusia: Pengadaan, Pengembangan, Pengkompensasian, dan Peningkatan Produktivitas Pegawai. Jakarta : Grasindo

Ghozali, Imam. 2009. Aplikasi Analisis Multivariate Dengan Program SPSS. Edisi Ketiga, Badan Penerbit Universitas Diponegoro, Semarang

Robbins. 2008. Manajemen. Jakarta : Indeks. Simamora, Henry. 2008. Manajemen Sumber Daya Manusia. Yogyakarta : Adi Citra Karya Nusa.
Sugiyono. 2009. Metode Penelitian Bisnis (Pendekatan Kuantitatif, Kualitatif, dan $R \& D)$. Bandung: Alfabeta

Sulistiyani, Ambar T. 2009. Manajemen Sumber Daya Manusia : Konsep, teori dan Pengembangan dalam Konteks Organisasi Publik. Yogyakarta : Graha Ilmu.

Swietenia, Rita. 2009. “Analisis Pengaruh Kepemimpinan, Kompensasi dan Karakteristik Pekerjaan Terhadap Disiplin Kerja Serta Implikasinya Terhadap Kinerja Pegawai (Studi Pada Kantor Pertanahan Kota Semarang)." Jurnal Ekonomi Manajemen - Akuntansi, No. 26, Th. XVI. 